\title{
Research on the Development of Exhibition Industry in Wuhan Under the COVID-19
}

\author{
Ruan Xiao \\ School of Business, Wuhan College of Arts \& Science, Wuhan, China, 430345 \\ ruanxiao123@sina.cn
}

\begin{abstract}
A disaster outbroke suddenly in Wuhan in December 2019. The tourism and exhibition industry is getting into trouble together as one of the three main economic industries. The epidemic situation has a significant impact on the economy and society in China, and even the global economy. As a result, the convention and exhibition industry has been influenced, even stop the work. In addition, a lot of meetings were canceled and delayed. The COVID-19 not only impacted the exhibition industry but also has challenges and opportunities. In the end, the research also gives some suggestions for the exhibition industry in the future.
\end{abstract}

Keywords: COVID-19; Exhibition Industry; Wuhan; Effect; Suggestion

\section{INTRODUCTION}

The convention and exhibition industry develops rapidly since the 1990s in China, but now it has enormous potential and strong power in the world, even though it was a later starter. With the continuation of the thorough reform of the economic system and the reform and opening-up policy, the convention and exhibition industry had entered a period of revolution and significant development after The Third Plenary Session of the 11th Central Committee of the Communist. Furthermore, the Chinese focused on the organization and management of the exhibition in the other country before the mid-1980s. China's exhibition industry become turn into international until they participated in the "Basel Sample Fair Event" in Switzerland. In 1999, China successfully held the 184 daysWorl Horticultural Exposition in Kunming. It means this is a new stage for the development of the Chinese exhibition industry. Up to now, the conference and exhibition industry has become the "bread" and the "business card" for the city and the country. Like a rising sun and the service industry, exhibition, tourism, and reality are the biggest three economic industries.

\section{THE SITUATION OF THE EXHIBITION INDUSTRY IN WUHAN}

\subsection{Exhibition Venues in Wuhan}

Wuhan has a lot of competitive exhibition centers. The first one is the Wuhan International Convention \& Exhibition Center, which is built-in 1956. This is the 4th biggest and comprehensive exhibition in China after Beijing, Shanghai, and Guangzhou at that time. It is 127,000 square meters in total, including 5,000 square meters for the exhibition hall. There are 2800 international standard booths can be set up. In addition, Wuhan Science and Technology Convention Center, which is located in east lake. It also is a large, intelligent, and multi-functional comprehensive convention center. It has not only a perfect conference hall but also includes office buildings, restaurants, hotels, apartments, and other supporting facilities. But this still does not has strong competitive advantages rather than other cities. Up to the built of the Wuhan International Expo Center in 2011, it means Wuhan is the main exhibition city in central China. Because it is the biggest exhibition in central city and the third in China at the moment. Wuhan International Expo Center can provide 6,880 standard international booths, which is 180,000 square meters. It is bigger than the 18 football field. Besides that, it also has the famous five-star hotel-Intercontinental hotel, Greenland center, music fountain, and the great landscape. In general, Wuhan's exhibition venues have strong competitiveness.

\subsection{The Status of Wuhan's Exhibition Industry in China}

According to the survey, Wuhan International Convention and Exhibition Center, Wuhan Cultural Expo Center, China Optical Valley Science and Technology Center, Wuhan International Expo Center hosted 1,600 exhibitions and received more than 10 million exhibitors and visitors in 2017, not including those small pavilions. However, according to the ranking of "The most Competitive Exhibition cities in China" released by The China Conference and Exhibition Economics Research Institute in 2017, Wuhan is not among the first-tier exhibition cities. In the final analysis, the reason is the exhibition scale is small although Wuhan has held many exhibition venues and received many people. Up to the 7th CISM Military World Games held successful in Wuhan in October 2019. As a result, Wuhan became a first-tier exhibition city and attracted worldwide attention. 


\section{THE IMPACT OF COVID-19}

\subsection{The Impact for Chinese Exhibition Industry}

Because of the COVID-19 and in order to manage the outbreak effectively, all companies stopped their works. For the exhibition industry, all exhibitions have been a delay and cancel. As a result, COVID-19 effect the exhibition industry seriously. According to the Chinese exhibition economy seminar COVID-19 outbreak impact on the global international convention industry research report, the data from February to June in 2020 from the international conference, shows that the COVID-19 mainly influence the Asia-Pacific countries, especially in China[1] It canceled almost 86 , changed 44 international meetings during the first 6 months this year. Changing proportion is as high as $51.16 \%$, which is the topper. According to this survey, it also shows if the COVID-19 is controlled and not come back at the end of this year, the global international conferences will resume at the end of 2020 . But the conferences in Asia-Pacific countries will not recover especially in China for the whole year.

Table 1. Table of changes in the global conference industry in the first half of 2020 under the impact of the epidemic

\begin{tabular}{|c|c|c|c|c|c|c|}
\hline & $\begin{array}{c}\text { Cancel } \\
\text { meeting }\end{array}$ & $\begin{array}{c}\text { Delay } \\
\text { meeting }\end{array}$ & $\begin{array}{c}\text { Move } \\
\text { meeting }\end{array}$ & $\begin{array}{c}\text { Plan to change } \\
\text { intotal(Jan-Jun) }\end{array}$ & $\begin{array}{c}\text { Actual } \\
\text { change }\end{array}$ & proportion \\
\hline $\begin{array}{c}\text { Asia-Pacific(included } \\
\text { China) }\end{array}$ & 42 & 111 & 8 & 336 & 161 & $47.92 \%$ \\
\hline China & 10 & 32 & 2 & 86 & 44 & $51.16 \%$ \\
\hline North America & 18 & 9 & 1 & 232 & 28 & $12.07 \%$ \\
\hline Europe & 61 & 101 & 6 & 1021 & 168 & $16.45 \%$ \\
\hline Latin America & 5 & 9 & 1 & 91 & 15 & $16.48 \%$ \\
\hline Africa & 2 & 18 & 1 & 69 & 21 & $30.43 \%$ \\
\hline Intotal & 128 & 248 & 17 & 1749 & 393 & $22.47 \%$ \\
\hline
\end{tabular}

Note: Changes include extension, cancellation, change of host city, etc. (Source: Study on the Impact of coVID-19 on the Global Conference Industry, 2020.04.13)

\subsection{The Influence of Wuhan's Eexhibition industry}

Wuhan was the city most affected by COVID-19, all the industry and company have effected in January of 2020. According to "Notice of Wuhan Novel Coronavirus Infection Prevention and Control Command", "Notice on Strengthening Prevention and control of Pneumonia Caused by Coronavirus and Strict control of related Travel Activities" and "Notice on Strengthening Prevention and control of Pneumonia Caused by Coronavirus Infection By Novel Coronavirus", required all exhibition venues to closed in Wuhan, and all exhibition activities will be canceled or delayed. Besides, the closure of Wuhan city has destroyed the exhibition industry in Wuhan. For the host organizer, it should be a long time to prepare the activities in advance and all the work are could be the cost and service. If the activities are canceled, they will lose the benefits absolutely. Moreover, it also has bad impacts on the stakeholders.

Even though the COVID-19 has a huge impact and loss of the benefits, but Wuhan's exhibition industry also has made great contributions during the protection of COVID-19[2]. Wuhan International Expo Center, Wuhan International Convention, and Exhibition Center, Wuhan Optics Valley Science and Technology Convention and Exhibition Center, Wuhan Sports Center, Wuhan Gymnasium, Wuhan Guest Hall, and other venues are the mobile cabin hospitals for free in the first time. They have fully fulfilled their social responsibilities and established a good reputation.

\section{THE FUTURE PROSPECT OF WUHAN'S EEXHIBITION INDUSTRY UNDER THE COVID-19}

The cities in China have basically returned to work because of the control of the COVID-19. The epidemic has not only brought a great impact on the exhibition industry but also brought opportunities. For instance, resource integration, industrial upgrading, and development of the online exhibition industry. Wuhan should establish and develop online exhibitions like Bejing. It can promote 
innovation of exhibition ways and reduced the influence of COVID-19 for the exhibition industry. What's more, this is a new opportunity for exhibitors. Due to the impact of the epidemic, exhibitors also need a place to show their products, advertising, find and maintain a good relationship with customers, to reduce their financial and economic pressures. However, it is just a few online platforms for the Wuhan convention and Exhibition industry, so the construction of the e-commerce platform needs to be improved. In addition to building online exhibition platforms, we also need developing technology and information networks to ensure digital transformation, intelligent upgrading, and integrated innovation[3]. With the development of live broadcasting and $5 \mathrm{G}$ networks, offline exhibition hall and online platform should be combined. The exhibition hall is not only a real existence but also is a live broadcasting platform and information distribution center.

From the government perspective, policies should be formulated to support the development of the exhibition industry[4]. The companies can start to work based on safety and prevention well. Secondly, the role of the industry association is also very important to strengthen the leadership and coordination role of the industry association. As a city with 1 million college students, and has more than 80 universities and colleges, which have competitive advantages in talent cultivation. At present, compared with tourism and hospitality management, there are just several universities or colleges that have exhibition management, so the construction of exhibition management should be strengthened. Finally, every exhibition hall should strengthen its own technology, conform to the advent of the $5 \mathrm{G}$ era, and plan a new model of integrated development of online and offline[5].

\section{CONCLUSION}

COVID-19 not only has a great impact on the exhibition industry in Wuhan but also brings opportunities to the industry. The epidemic is a major change in the exhibition industry, and the limitations of offline are gradually exposed. The whole industry is thinking about how to develop the exhibition in the future. In addition, the conference and exhibition industry should make full use of $5 \mathrm{G}$, VR/AR, big data, and other modern information technology, combine online and offline, and strive to develop new models.

\section{REFERENCES}

[1] ICCA(CIMERT). (2020). The impact of the COVID-19 on Global Exhibition Event. China Convention/ Exhibition/ Event Society. Website:http://www.cces2006.org/index.php/home/index/d etail/id/13494, China Conference and Exhibition Economics Research Association.
[2] Jiang, X., F. (2020). Innovation of exhibition Service Mode by Science and Technology -- China Optical Valley Science and Technology Exhibition Center will build online and offline exhibition closed-loop service. China Convention and Exhibition, 2020(09):48-49.

[3] Li, Z., J. (2020). What will happen to the exhibition industry in the "post-epidemic era"?. China Exhibition and Exhibition,2020(09):28-37+11.

[4] Tang, J., Li, Y., L., Li, Q., Q., \& Luo, M., T.(2020). Impact of COVID-19 on exhibition industry and Countermeasures. Business Culture,2020(12):46-47.

[5] Li, W., J. (2020). Impact of the normalization of COVID-19 prevention and control on the Exhibition industry in Henan Province and countermeasures. Decision-making Exploration (Part 1),2020(06):30-32. 